East African Journal of Science, Technology and Innovation, Vol. 1 (1): 2019, 27-51.

This article is licensed under a Creative Commons license, Attribution 4.0 International (CC BY 4.0)

\title{
Ethno-varieties and distribution of jackfruit tree (Artocarpus heterophyllus Lam.) in Uganda: implications for trade, food security and germplasm conservation
}

\author{
${ }^{1 *}$ NAKINTU J., ${ }^{1}$ OLET A E., ${ }^{2}$ ANDAMA M., ${ }^{1}$ LEJJU B J
}

\author{
${ }^{1}$ Department of Biology, Mbarara University of Science and Technology, \\ ${ }^{2}$ Department of Biology, Muni Univesrity \\ ${ }^{*}$ Corresponding author: jnakintu@must.ac.ug
}

\begin{abstract}
Artocarpus heterophyllus Lam. is a fruit tree crop largely grown in tropical regions for its edible fruits. Though listed among underutilized crops, the demand for jackfruit in Uganda has increased. Amidst the increase in demand, the crop faces strong selective pressure and yet there is no documentation of the varieties and distribution of the crop in the country. This study therefore aimed at determining the varieties and distribution of jackfruit in Uganda using folk knowledge to provide a baseline for its production, booming market and conservation. A cross-sectional survey involving 349 participants comprising of 205 jackfruit traders and 144 jackfruit farmers from three political regions and three agroecological zones was conducted. Data were collected through face to face interviews using a semistructured questionnaire and direct observations. Classification of jackfruit varieties, geographical location of the source of jackfruits for traders and the time of harvest of the fruit by the farmers were investigated. Occurrence of varieties per household was determined through on-farm visits. Data analysis techniques involved descriptive, chi-square and Cramer's V measure of association analyses. Traders mainly obtained jackfruit from Central $(46.0 \%)$ and Eastern (37.6\%) political regions, Lake Victoria Crescent and Mbale Farmlands (41.1\%) and Southern and Eastern Lake Kyoga Basin (30.0\%) agro-ecological zones. Jackfruit varieties were classified basing on fruit texture and pulp colour, revealing four ethno-varieties, soft (Serebera), firm yellow (Kanaanansi), firm red (Namusaayi) and firm white (Namata). Namata and Serebera registered the lowest occurrences in political regions and agro-ecological zones. Farmers harvested jackfruit throughout the year with a peak season in December and January. Folk knowledge provided baseline information for jackfruit variety categorization. Selection pressure exerted on Serebera and Namata demands for germplasm conservation. Since jackfruit thrives in a wide range of climatic conditions, its cultivation should be encouraged to ensure food security and sustain the increasing demand.
\end{abstract}

Keywords: Artocarpus heterophyllus; Ethno-varieties; Folk taxonomy; germplasm conservation; Uganda

Cite as: Justine Nakintu et al, 2019 Ethno-varieties and distribution of

Received: $\quad$ 18/07/19

jackfruit tree (Artocarpus heterophyllus Lam.) in Uganda:

Accepted: $\quad 04 / 10 / 19$ implications for trade, food security and germplasm conservation.

Published: $\quad$ 25/10/19

East African Journal of Science, Technology and Innovation 1(1): 27-51 


\section{Introduction}

Jackfruit (Artocarpus heterophyllus Lam.) is a medium sized ever green tree with a height ranging from 8 to $25 \mathrm{~m}$ and produces the heaviest tree born fruit weighing up to $80 \mathrm{~kg}$ (Rahman, Patwary, Barua, Nahar, and Ahmmed, 2016; Shyamalamma, Chandra, Hegde, and Naryanswamy, 2008; Sidhu, 2012). In its geographical range (Asia, Africa and South America), it is mostly grown for its nutritious big fruits (Borines et al., 2014; Haq, 2006). Due to the big size of its fruits, in Uganda, jackfruit is known as Ffenensi or Ffene derived from a Luganda language phrase "Ffena ensi tulya kuno", literally meaning that the fruit can feed the whole world (Nakintu et al., 2019). In addition to its nutritious fruits, jackfruit tree is a source of fuel, timber, medicine and fodder (Borines et al., 2014; Haq, 2006). In some countries such as the Philippines, jackfruit is a highly valued fruit providing sustainable income to farmers through local markets and export (Borines et al., 2014) and this is gradually being realized in Uganda with jackfruit marketing and consumption being evident in most urban centers of the country. Over the last decade, jackfruit has presented itself as a fruit crop with a potential of alleviating poverty and providing food security for both rural and urban communities (MagcaleMacandog, Rañola, Rañola, Ani, and Vidal, 2010). For this to be achieved, jackfruit production should follow suite. Nevertheless, jackfruit cultivation in Uganda is currently experiencing two antagonistic events, cutting down of jackfruit trees (Ndyomugyenyi, Okot, and Mutetikka, 2014) and planting of the fruit tree (unpublished field observations). These events depict existence of selection pressures towards the crop which may threaten its genetic resource and food security in the country (Esquinas-Alcázar, 2005). For instance strong human selection has been reported to be responsible for creating genetic bottlenecks (Hyten et al., 2006) leading to reduction of crops' genetic diversity (Turyagyenda et al., 2012; Wang, 2011). Despite the existence of selection pressures against the crop, recent findings revealed that Uganda harbors high genetic diversity of jackfruit
(Nakintu et al., 2019). However, the genetic information needs to be complemented by documentation of ethno-varieties of jackfruit and its distribution in the country. This will safeguard the crop's genetic information that can be utilized for crop improvement as reported by Khan et al. (2010) in Bangladesh. Therefore, as production, marketing and consumption of jackfruit intensify in the country, it is crucial to determine the varieties that exist in order to inform germplasm conservation and aid future breeding and improvement programs (Oldfield, Olwell, Shaw, and Havens, 2019).

Being one of the underutilized crops in Uganda and the rest of the world (Haq, 2006), the crop has attracted little research interest in the country with just a few studies done on it as a potential source of animal feed (Ndyomugyenyi et al., 2014) despite the increasing demand for its fruit and wood amidst strong human selection pressure. According to Mota et al. (2019), food insecurity and undernourishment are prevalent in many developing countries, Uganda inclusive. However, underutilized crops such as jackfruit endowed with various nutritional values and calories (Ranasinghe, Maduwanthi and Marapana, 2019) can play an important role in reducing these problems if given attention. Therefore, this study provides insights into jackfruit taxonomy and distribution in Uganda which can be utilized in selecting superior varieties for multiplication to ensure food security, sustainability of the jackfruit trade in the country and devise suitable conservation strategies for inferior varieties to prevent genetic erosion.

The history of Uganda indicates that jackfruit was introduced by Asians in the 1890s (Dutton, 1976). With more than 100 years of interaction with the crop, undocumented folk knowledge on the taxonomy of the varieties of jackfruit should be available to form a basis for selection of the fruit by farmers, traders and consumers. Folk knowledge is a crucial component of ethnobotany and ethno-zoology because it provides information on human-plant/animal interactions (Gras, Serrasolses, Vallès and Garnatje, 2019; Ulicsni, Svanberg and Molnár, 2013, 2016). 
According to Gwali et al. (2011) information on crop varieties and their desired traits is often available in traditional/folk knowledge. Tibuhwa (2012), describes folk taxonomy as the classification of organisms on the basis of cultural tradition which uses the vernacular naming system. It involves the use of social knowledge and the way people interact with the natural surroundings in their daily speech. Folk taxonomy differs from scientific taxonomy in that it is entrenched with social relations and is therefore not universal. Despite that limitation, folk taxonomy has been reported to be biologically accurate (Berlin, 2014; Loko et al., 2018) and its value is rapidly gaining recognition for its usefulness in identifying new resources, guiding conservation strategies (Kakudidi, 2004) and breeding programs (Gwali et al., 2011) due to the diversity of information it bears on the biology, ecology and ethology of different groups of fauna and flora (Phaka, Netherlands, Kruger and Du Preez, 2019; Ramires, Clauzet and Begossi, 2012). For example, traditional knowledge has been used to develop breeding programs of many plant species including but not limited to potatoes (Quiros, Brush, Douches, Zimmerer, and Huestis, 1990), sorghum (Mekbib, 2007), cassava in Brazil (Sambatti, Martins, and Ando, 2001) and rice in Laos and Gambia (Nuijten and Almekinders, 2008; Rao, Bounphanousay, Schiller, Alcantara, and Jackson, 2002). Gwali et al. (2011) argues that traditional knowledge is highly organized and structured that plants can be categorized according to life form, genus, and varietal level. In addition, folk classification accommodates utilitarian, psychological, and linguistic factors making it important for categorizing landraces as well as studying their distribution (Teshome et al., 1997).

Shyamalamma et al. (2008), reported absence of well-defined jackfruit varieties in Southern India and local communities had different names for different varieties based on variability in yield, flake colour, and total sugars, portraying the importance of local communities in classification. In addition, Ulicsni et al. (2016) recognized the importance of humans living in close contact with the environment such as herdsmen and peasants who possess unique and systematic folk knowledge on flora and fauna on which they attach importance. This study therefore, aimed at determining the varieties and distribution of jackfruit in Uganda using the traditional knowledge of jackfruit traders and farmers through face to face interviews using a semistructured questionnaire and on-farm visits through which occurrences of the ethno-varieties were confirmed. We hypothesized that since famers and traders regularly interact with jackfruit, then they should have some way of classifying it.

\section{Materials and Methods}

\section{Research design and data collection}

This study adopted a cross-sectional survey design employing both qualitative and quantitative methods. The survey was conducted from May 2017 to December 2018 covering 30 districts for traders and 12 districts for farmers representing three major jackfruit growing political regions (Central, Eastern and Western) and three agro-ecological zones (Lake Victoria Crescent and Mbale Farmlands, LVCMF, Southern and Eastern Lake Kyoga Basin, SELKB and South Western Grass Farmlands, SWGF) (Wortmann and Eledu, 1999).The political regions harbor different tribes including Baganda in the Central region, Basoga, Bagishu and Itesots in the East and Bakiga and Banyakore in Western Uganda. Selection of the sampling sites was based on results of the pilot survey conducted among traders in four major towns of Uganda (Kampala in the Central region, Jinja in the East, Mbarara in the Western region and Gulu in Northern Uganda). Of the 42 traders interviewed in the pilot survey, $52.4 \%$ obtained jackfruit from Eastern region, 35.7\% from the Central, $11.9 \%$ from the West and no trader reported getting jackfruit from the Northern region. Therefore, Northern Uganda was not included in the final survey. In addition, traders mentioned 23 districts from which they obtained jackfruit namely Mityana, Masaka, Mubende, Mukono, Mbale, Mpigi, Wakiso, Luweero, Jinja, Kamuli, Mayuge, Iganga, Kayunga, Namutumba, Bugiri, Buikwe, Sironko, Budaka, Kibuku, Ibanda, 
Mbarara, Pallisa and Nakasongola. These districts belong to five agro-ecological zones, Lake Victoria Crescent and Mbale Farmlands (LVCMF), Southern and Eastern Lake Kyoga Basin (SELKB), South Western Grass Farmlands (SWGF), Western Mid-Altitude Farmlands and the Semiliki Flats (WMAFSF) and Central Wooded Savanna (CWS). Since most of the districts belonged to LVCMF, SELKB, and SWGF agro-ecological zones, these zones were selected for the final survey. Jackfruit traders were sampled from major towns of 30 randomly selected districts with 10 districts representing an agro-ecological zone (Figure 1). Among the 30 districts, 12 were selected for studying farmers based on their production in an agro-ecological zone. The top four districts in production were selected from each agro-ecological zone, LVCMF (Iganga, Jinja, Masaka and Mityana); SELKB (Pallisa, Kamuli, Kayunga and Luweero); SWGF function of supply to the markets. Farmers were randomly selected from two sub-counties in each district. Data were collected through face to face interviews among jackfruit traders and farmers using a pre-tested semi-structured questionnaire and direct observations. Classification of jackfruit varieties based on folk knowledge of Ugandan societies, geographical location of the source of jackfruits for traders and the time of harvesting the fruit by the farmers were investigated. Occurrence of ethno-varieties per household was determined through on-farm visits during which the number of households where each variety occurred was recorded. The distribution of jackfruit ethno-varieties was estimated as the percentage of households where the variety occurred. Luganda folk names were used throughout the text because it is the most common local language spoken in many parts of Uganda.

(Mubende, Sembabule, Ibanda and Mbarara,

Figure 1). Production was determined as a

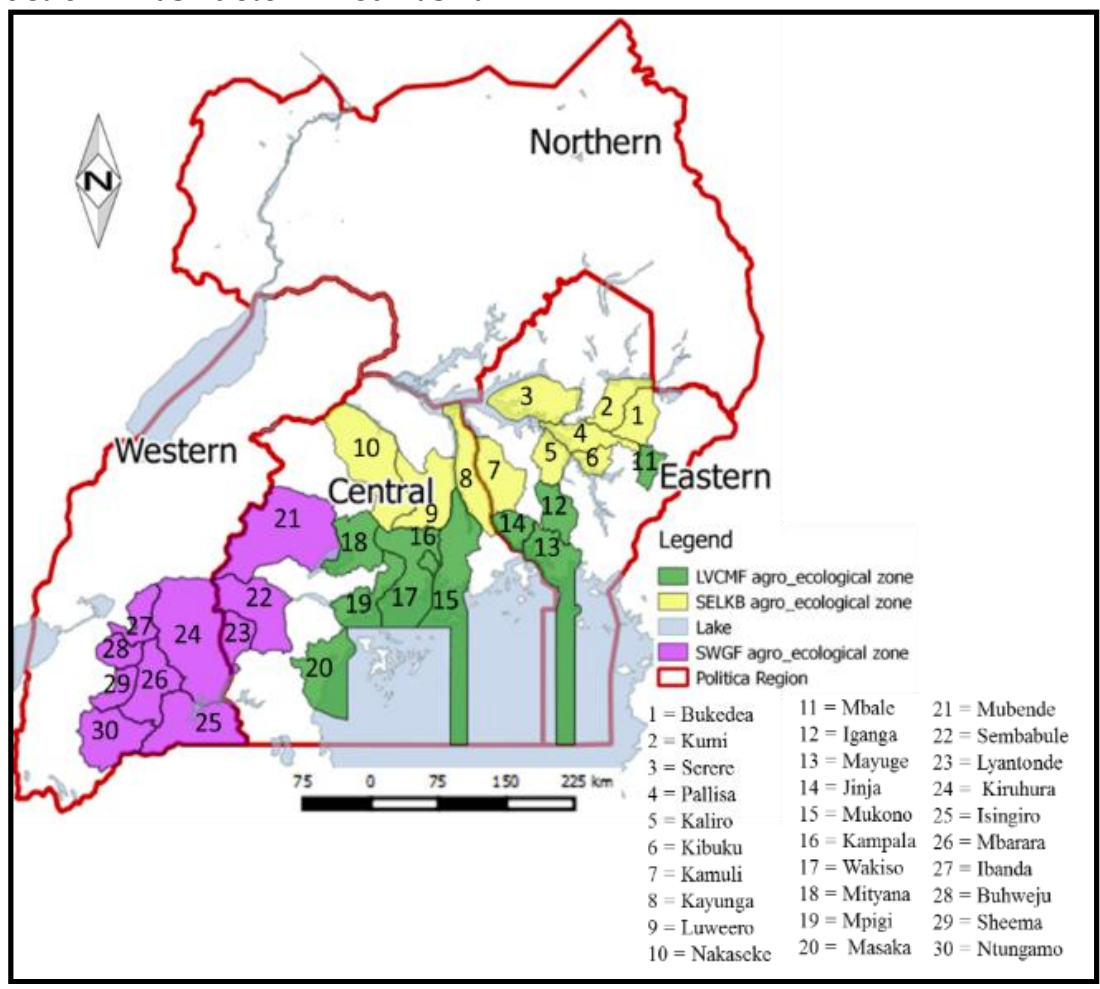

Figure 1: Map showing agro-ecological zones, political regions and the respective districts sampled (QGIS Version 2.6.1-1). LVCMF = Lake Victoria Crescent and Mbale Farmlands; SELKB = Southern and Eastern Lake Kyoga Basin; SWGF = South Western Grass Farmlands 


\section{Data analysis}

Results were descriptively and statistically analyzed using Excel 2013 and SPSS version 20. Chi-square tests were computed at 95\% level of confidence. To test for association, demographic data and results on variety classification according to fruit texture as well as occurrence of the varieties were cross tabulated in SPSS and Cramer's $\mathrm{V}$ analysis done.

\section{Results and discussion}

\section{Demographic characteristics}

A total of 349 respondents (205 jackfruit traders and 144 jackfruit farmers) aged 18 to 83 years were interviewed and their demographic characteristics are summarized in Table 1 . Of the 205 jackfruit traders, $60.0 \%$ were females and $40.0 \%$ were males while, $54.9 \%$ of jackfruit farmers $(n=144)$, were females and $45.1 \%$ were males. Similar results were obtained by Chiputwa and Qaim, (2016) among coffee farmers and traders portraying the contribution of women to the development of the agricultural sector in Uganda. Among the respondents, 58.3\% of farmers and $51.7 \%$ of traders had attained their primary level of education. This is in conformity with national attainment of education in that, majority of Ugandans have attained primary education (Uganda Bureau of Statistics, 2017). 
Table 1 Demographic Features of the Respondents

\begin{tabular}{|c|c|c|c|c|}
\hline \multirow[b]{2}{*}{ Features } & \multicolumn{2}{|c|}{ Farmers } & \multicolumn{2}{|l|}{ Traders } \\
\hline & Frequency & Percent & Frequency & Percentage \\
\hline \multicolumn{5}{|l|}{ Sex } \\
\hline Female & 79 & 54.9 & 123 & 60.0 \\
\hline Male & 65 & 45.1 & 82 & 40.0 \\
\hline \multicolumn{5}{|l|}{ Education Level } \\
\hline None & 31 & 21.5 & 32 & 15.6 \\
\hline Primary & 84 & 58.3 & 106 & 51.7 \\
\hline Secondary & 18 & 12.5 & 55 & 26.8 \\
\hline Tertiary & 11 & 7.6 & 12 & 5.9 \\
\hline \multicolumn{5}{|l|}{ Age range } \\
\hline $18-27$ & 13 & 9 & 53 & 25.9 \\
\hline $28-37$ & 26 & 18.1 & 64 & 31.2 \\
\hline $38-47$ & 43 & 29.9 & 53 & 25.9 \\
\hline $48-57$ & 22 & 15.3 & 22 & 10.7 \\
\hline$>57$ & 40 & 27.8 & 13 & 6.3 \\
\hline \multicolumn{5}{|l|}{ Main Occupation } \\
\hline Livestock farming & 1 & 0.7 & 0 & 0 \\
\hline Mixed farming & 1 & 0.7 & 0 & 0 \\
\hline Salaried & 10 & 0.7 & 5 & 2.4 \\
\hline Crop farming & 115 & 79.9 & 8 & 3.9 \\
\hline Trader & 1 & 0.7 & 173 & 84.4 \\
\hline Others & 16 & 11.1 & 19 & 9.3 \\
\hline \multicolumn{5}{|l|}{ Marital status } \\
\hline Single & 19 & 13.2 & 66 & 32.2 \\
\hline Married & 100 & 69.4 & 125 & 61.0 \\
\hline Divorced & 7 & 4.9 & 7 & 3.4 \\
\hline Widowed & 18 & 12.5 & 7 & 3.4 \\
\hline \multicolumn{5}{|l|}{ Region } \\
\hline Central & 72 & 50.0 & 103 & 50.2 \\
\hline Eastern & 48 & 33.3 & 66 & 32.2 \\
\hline Western & 24 & 16.7 & 36 & 17.6 \\
\hline \multicolumn{5}{|l|}{ AEZ } \\
\hline LVCMF & 50 & 34.7 & 93 & 54.4 \\
\hline SELKB & 49 & 34.0 & 63 & 30.7 \\
\hline SWGF & 45 & 31.3 & 49 & 23.9 \\
\hline
\end{tabular}

LVCMF = Lake Victoria Crescent and Mbale Farmlands, SELKB = Southern and Eastern Lake Kyoga Basin, SWGF $=$ South Western Grass Farmlands 


\section{Ethno-varieties of jackfruit}

The survey (Table 2) revealed that in Uganda, jackfruit was locally classified based on fruit texture (soft or firm) and pulp colour (white, yellow and red/pink/orange, Figure 2) and varieties were awarded local names that were synonymous to either fruit texture or the pulp colour (Table 2). Jackfruit folk classification among traders and farmers revealed that pulp colour was universally utilized by all respondents. The consistency of using pulp colour displayed by traders and farmers from different political regions belonging to different ethnic backgrounds portrayed existence of shared indigenous knowledge on classification and environment of the fruit (Nuijten and Almekinders, 2008) thus confirming the consistency of folk classification as reported by Berlin (2014). Folk classification has also been utilized to obtain ethno-varieties of shear butter tree in Uganda (Gwali et al., 2011) and common bean in Benin (Loko et al., 2018) and use of colour was strongly relied on among other criteria. Pulp colour has also been used in India to categorize jackfruit varieties (Shyamalamma et al., 2008) though with finer divisions of the colours resulting into cream, white, light yellow, deep yellow, lemon yellow, light saffron, saffron, orange and deep orange varieties (Jagadeesh et al., 2007; Ranasinghe et al., 2019). Overall, only $37.5 \%$ of the farmers $(n=144)$ classified jackfruit according to fruit texture with varying proportions contributed by political regions $($ Central $=85.2 \%$, Eastern region $=11.1 \%$, Western $=3.7 \%$ Figure 3a). Comparable results were obtained from traders with only $33.7 \%$ ( $n=$ 205) classifying jackfruit according to fruit texture with the Central region contributing the highest proportion (84.1\%), followed by the Eastern region $(8.7 \%)$ and Western region the lowest $(7.2 \%)$ as shown in Figure 3b. Fruit texture has also been utilized in many other countries such as Sri Lanka (Hossain and Haq, 2006), Brazil (Madruga et al., 2014; Maia, Andrade, and Maria das Gracas, 2004), China (Li, Qi, Feng, and Ye, 2010) and India (Shyamalamma et al., 2008). Although fruit texture has been used worldwide, in Uganda, pulp colour was more recognized than fruit texture and classification of jackfruit according to fruit texture showed medium to large significant association to political regions, $(\mathrm{V}=0.483, \mathrm{p}=0.000$ among traders and $\mathrm{V}=0.546$, $p=0.000$ among farmers, Table 5). This may be attributed to scarcity of the soft variety or low importance attached to it in Uganda to the extent that some respondents especially in the Western and Eastern regions had never seen the soft variety and therefore only categorized the firm / hard variety based on the pulp colour (unpublished field observations). The scarcity of the soft variety in the country may be due to the fact that it is considered to be of poor quality and low consumption demand hence planted by a few farmers. Similar scenarios have been reported in Bangladesh (Khan, Zerega, Hossain, and Zuberi, 2010) and India (Ranasinghe et al., 2019) with inferior jackfruit germplasm thriving only in the wild and superior varieties grown in homesteads. In China, flowering time and fruiting are also used to classify jackfruit as annual mature type and biannual mature type ( $\mathrm{Li}$ et al., 2010). However, in Uganda, none of the farmers or traders used this criterion. This may be attributed to differences in life cycles of jackfruit in Uganda and China or existence of different varieties in the two countries. Though there are some noticeable differences in the way jackfruit varieties are categorized in different countries, the use of fruit texture and pulp colour seem to be consistent worldwide. In addition, a study conducted on the Genetic diversity of jackfruit grown in Uganda revealed two genetic clusters and one of the clusters was closely related to samples from Asia ((Nakintu et al., 2019) suggesting existence of similar varieties or shared ancestral origin. 


\begin{tabular}{|c|c|c|c|c|}
\hline \multirow[b]{2}{*}{ Language } & \multicolumn{4}{|c|}{ Ethno-varieties } \\
\hline & Soft & Firm White & Firm Yellow & Firm Red/Pink/Orange \\
\hline Luganda & $\begin{array}{l}\text { Jebu, Njebu, } \\
\text { Serebera, Nuuna }\end{array}$ & Namata & Kanaanansi & Namusaayi \\
\hline Lusoga & Erikutena & Edheru & Kapapali & Omutukuriki \\
\hline Lugishu & Siwulo & Iwanga & Nabuloba & Imbesemu \\
\hline Ateso & Enonok & Ekwang & Idosoikit & Ereng \\
\hline Runyankore & Miluku & Erikweera & Eyakyenju & Erikutukura \\
\hline Rukiga & Eyorobi & Eyamutale & Kinekye & Erikutukura \\
\hline
\end{tabular}

Table 2 Ethno-varieties of jackfruit in Uganda and their respective local language names

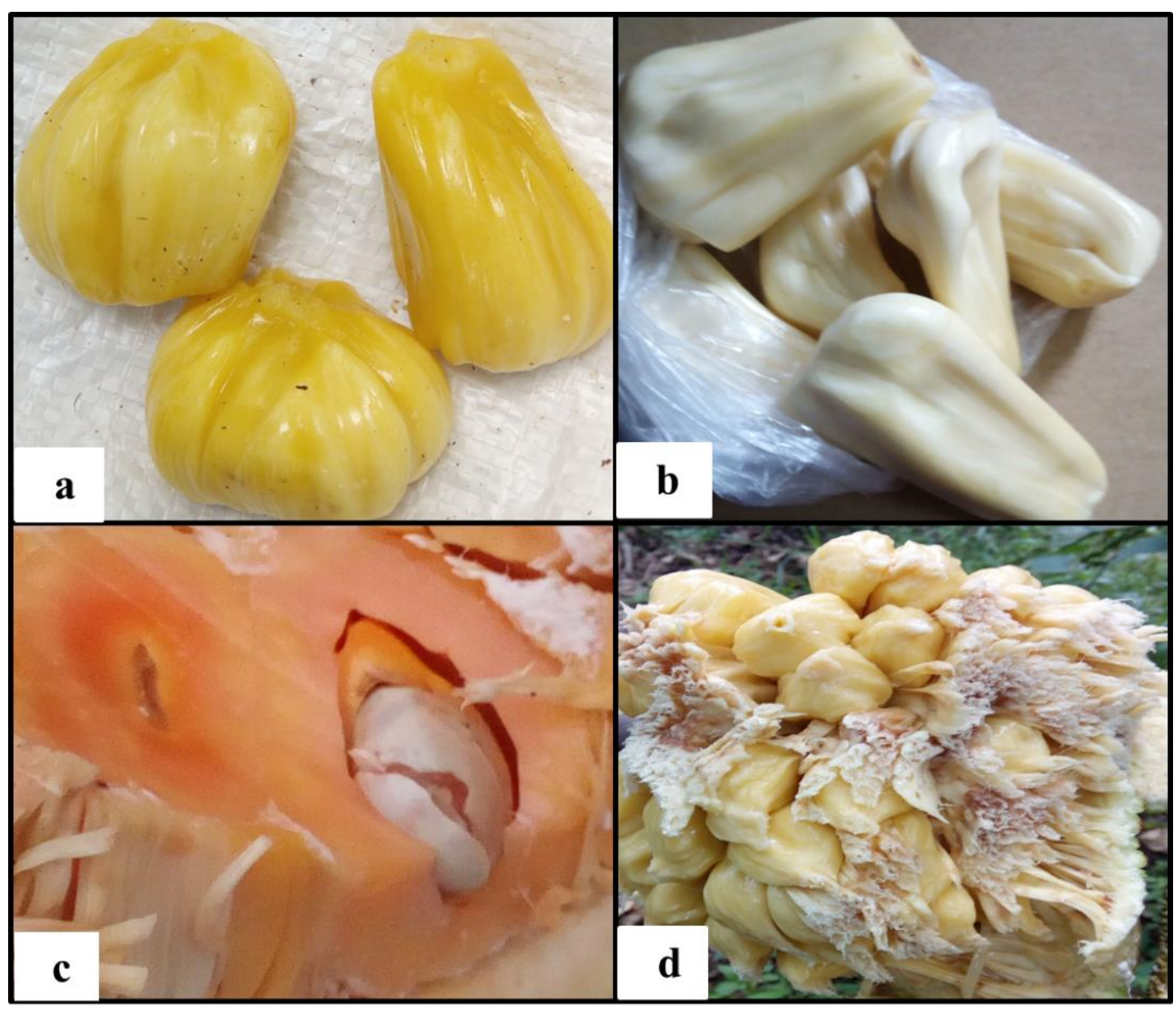

Figure 2: Ethno-varieties of jackfruit; (a) Kanaanansi (b) Namata (c) Namusaayi (d) Serebera 


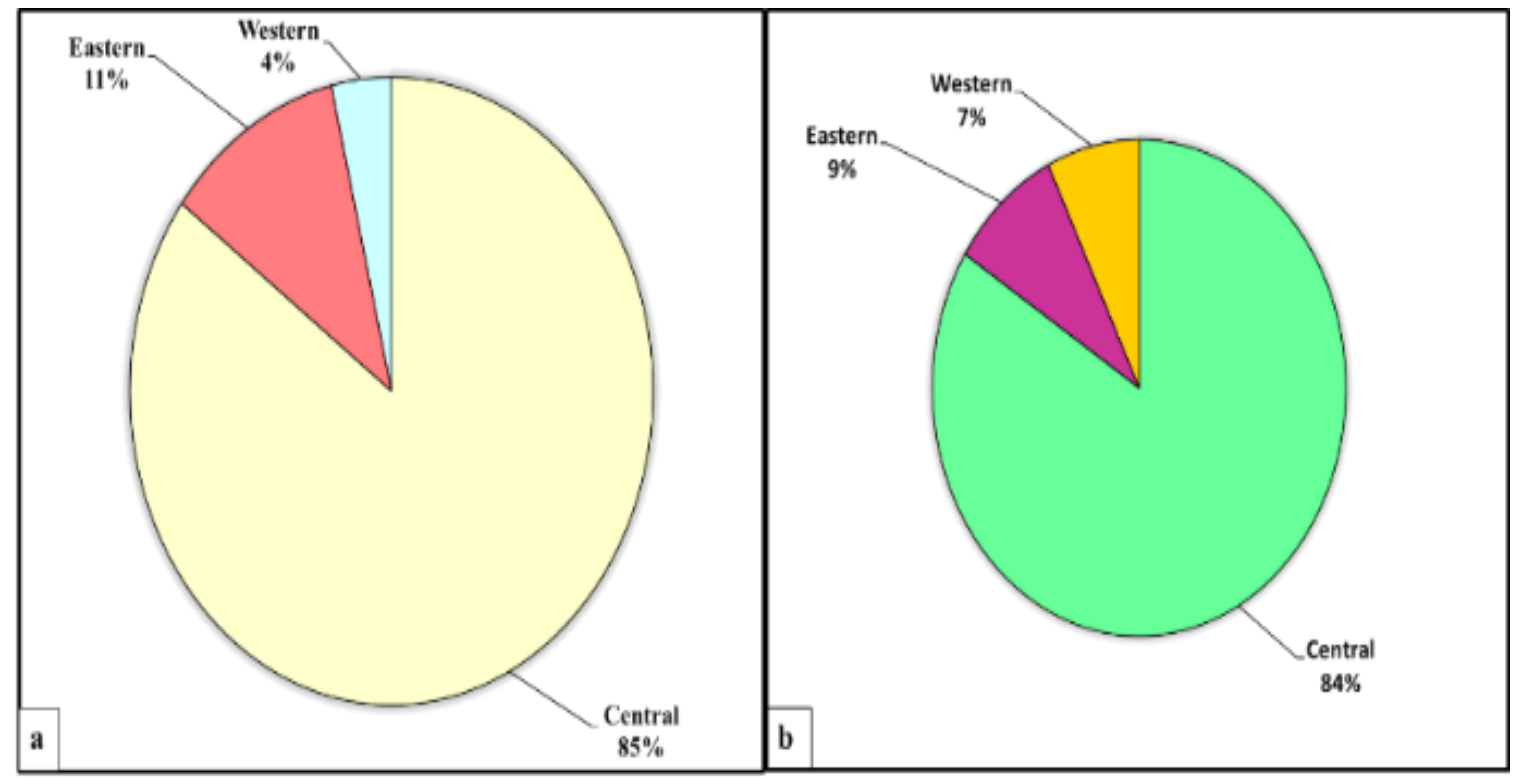

Figure 3

(a) Proportion of farmers ( $\mathrm{N}=54$ of 144 farmers) (b) proportion of traders ( $\mathrm{N}=69$ of 205 traders) that classified jackfruit according to texture

\section{Distribution of jackfruit in Uganda}

The 205 jackfruit traders reported obtaining jackfruit from 41 districts (Table 3). These may not be the only districts producing jackfruit in Uganda but might have been listed due to their proximity to the sampled market. However, the data from traders on the districts where they obtained jackfruit from was paramount on a wider perspective to inform on the political regions and agro-ecological zones of Uganda where jackfruit is grown (Figure 4). Therefore, the districts mentioned by traders belonged to three political regions (Central, Eastern and Western, as shown in Table 4). The Central $(46.0 \%)$ and Eastern (37.6\%) regions, however, appeared more prominently than the Western region $(16.4 \%)$ which may be a consequence of historical neglect of the crop due to mythical issues related to jackfruit killing livestock (unpublished observations) since the Western region is dominated by cattle keeping communities. This puts the Central and Eastern regions at the center of jackfruit production supplying most of the jackfruit markets in
Uganda. Ndyomugyenyi et al. (2014) also reported high production in Kampala and Mbale, districts belonging to Central and Eastern regions respectively. No trader mentioned obtaining jackfruit from any district belonging to the Northern region (Figure 4a) even in the pilot survey in which it was represented by Gulu district suggesting absence or scarcity of jackfruit in this part of the country. The absence or scarcity of jackfruit in the Northern region may be attributed to seasonal bush burning which is predominant in the area since the plant is very sensitive to fire and high temperature (Hossain and Haq, 2006). Alternatively, people in the Northern region might have not taken keen interest in growing jackfruit. However, to ensure food security, it is important to set up field trials in the Northern region to establish whether jackfruit can adequately thrive in this part of the country.

Final survey results from traders were consistent with the pilot data revealing that the districts from which traders obtained jackfruit belonged 
to five agro-ecological zones (LVCMF, SELKB, SWGF, WMAFSF and CWS) as indicated in Figure $4 b$, although jackfruit has been reported to perform best in warm and moist regions (Bose, 1985; De Faria, De Rosso, and Mercadante, 2009). These results manifest the ability of jackfruit to thrive in wide range of environmental conditions (Haq, 2006; Hossain and Haq, 2006) hence serving a crucial role of ensuring food and nutritional security amidst different environmental settings prevailing in the agroecological zones of Uganda. The wide adaptation of jackfruit to various environmental conditions makes it a suitable food and cash crop for countries with a wide range of climatic conditions especially in the tropical region. 
Table 3: Frequencies of responses from traders on districts from which they obtained jackfruit and their respective agro-ecological zones and regions in Uganda

\begin{tabular}{|c|c|c|c|c|c|}
\hline \multirow[t]{2}{*}{ Region } & \multicolumn{5}{|c|}{ Agro-ecological zone } \\
\hline & LVCMF & SELKB & CWS & SWGF & WMAFSF \\
\hline \multirow{9}{*}{ 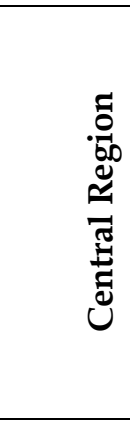 } & Butambala $1(0.2)$ & aLuweero 24 (5.4) & aNakasongola 5 (1.1 & aMubende 13 (2.9) & aMubende 13 (2.9) \\
\hline & aKayunga 30 (6.8) & aNakaseke 6 (1.4) a & aNakaseke 6 (1.4) & Sembabule 10 (2.3) & Kiboga 5 (1.1) \\
\hline & aLwengo 2 (0.5) & aKayunga 30 (6.8) & aKiboga 5 (1.1) & aLwengo $2(0.5)$ & \\
\hline & aLuweero 24 (5.4) & aNakasongola 5 (1.1) & & Gomba $1(0.2)$ & \\
\hline & Masaka 23 (5.2) & & & & \\
\hline & Mityana 23 (5.2) & & & & \\
\hline & Mpigi 14 (3.2) & & & & \\
\hline & Mukono 16 (3.6) & & & & \\
\hline & Wakiso 7 (1.6) & & & & \\
\hline \multirow{9}{*}{ 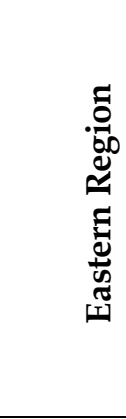 } & Jinja 35 (7.9) & Kamuli 28 (6.3) & & & \\
\hline & Mbale 11 (2.5) & Pallisa 20 (4.5) & & & \\
\hline & Mayuge 20 (4.5) & Buyende $1(0.2)$ & & & \\
\hline & Iganga $21(4.8)$ & Kaliro 11 (2.5) & & & \\
\hline & Namutumba 10 (2.3) & Budaka $10(2.3)$ & & & \\
\hline & Bugiri $2(0.5)$ & Bukedea 7 (1.6) & & & \\
\hline & Buikwe 1 (0.2) & Luuka 6 (1.4) & & & \\
\hline & Sironko 9 (2.0) & Kibuku 9 (2.0) & & & \\
\hline & & Serere $2(0.5)$ & & & \\
\hline \multirow{6}{*}{ 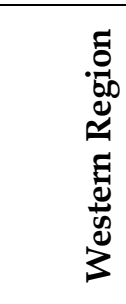 } & & & & Isingiro $3(0.7)$ & Hoima $2(0.5)$ \\
\hline & & & & Kiruhura $2(0.5)$ & Rubirizi $1(0.2)$ \\
\hline & & & & Ibanda $21(4.8)$ & \\
\hline & & & & Mbarara 15 (3.4) & \\
\hline & & & & Sheema 3 (0.7) & \\
\hline & & & & Ntungamo (2.3) & \\
\hline
\end{tabular}

aDistricts belonging to more than one agro-ecological zone, LVCMF = Lake Victoria Crescent and Mbale Farmlands, SELKB = Southern and Eastern Lake Kyoga Basin, SWGF = South Western Grass Farmlands, WMAFSF $=$ Western Mid-Altitude Farmlands and the Semiliki Flats, CWS $=$ Central Wooded Savanna 

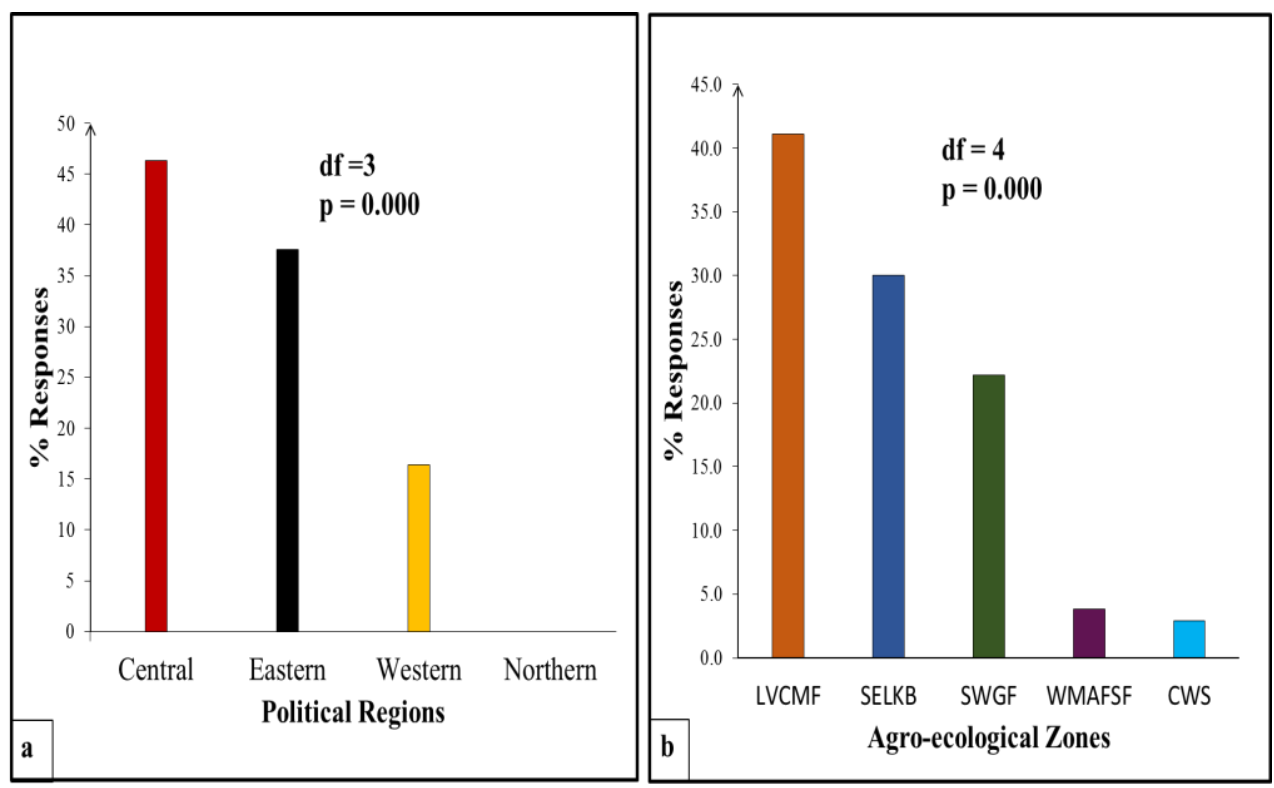

\section{Figure 4}

(a) Political regions (b) Agro-ecological zones from which traders obtained jackfruit. LVCMF = Lake Victoria Crescent and Mbale Farmlands, SELKB = Southern and Eastern Lake Kyoga Basin, SWGF = South Western Grass Farmlands, WMAFSF = Western Mid-Altitude Farmlands and the Semiliki Flats, CWS = Central Wooded Savanna

\section{Distribution of Ethno-varieties of jackfruit}

The results for on farm occurrence of ethnovarieties of jackfruit in 12 districts from the three political regions (Central, Eastern and Western) and three agro-ecological zones (LVCMF, SELKB, SWGF) are summarized in Table 4 and Figure 5 respectively. Overall, Kanaanansi was the most prevalent variety occurring in $94.4 \%$ of the farms in the political regions followed by Namusaayi (63.9\%). The occurrence of Namusaayi $(\mathrm{p}=0.986)$ and Kanaanansi $(\mathrm{p}=$ 0.668 ) did not significantly differ among political regions though the Eastern region $(72.9 \%)$ and Eastern/Western regions $(95.8 \%)$ recorded the highest occurrences of Namusaayi and Kanaanansi respectively (Table 4). Serebera (13.9\%) and Namata (29.2\%) registered the lowest and second lowest on farm occurrences among political regions and their occurrences significantly differed among the political regions $(p=0.000)$. Cramer's V measure of association revealed medium and significant associations between occurrence of Namata and political regions $(\mathrm{V}=0.312, \mathrm{p}=0.001)$ as well as occurrence of Serebera and political regions $(\mathrm{V}=$
0.281, $\mathrm{p}=0.030$, Table 5) with the Central region registering the highest occurrences of both Serebera $(23.6 \%)$ and Namata (43.1\%). Similarly, Kanaanansi occurred most in the three agroecological zones (LVCMF, SELKB, WGF) followed by Namusaayi, Namata and lastly Serebera (Figure 5). However the occurrences of all the ethno-varieties did not significantly vary ( $p>0.05$ ) among the agro-ecological zones (Figure 5) neither did they show significant associations to agro-ecological zones (Table 5). The wide distribution of Kanaanansi and Namusaayi may be attributed to the preference of Ugandans for these two varieties. These two varieties are regarded to be attractive and sweet and therefore with high demand on the market. As a result, every farmer wishes to plant either Kanaanansi or Namusaayi (unpublished field observation) therefore their occurrences showed no significant association to demographic data (Table 5). Similarly, in Bangladesh, jackfruit marketability formed a basis for selection of germplasm for growing in homesteads (Khan et al., 2010). Kanaanansi and Namusaayi are firm varieties and firm varieties have been considered 
superior to soft varieties not only in Uganda but in other countries as well such as India (Ranasinghe et al., 2019). The low occurrence of Serebera recorded in this study (Table 4 and Figure 5) may be due to its perishability which makes its fruits difficult to transport over long distances hence limiting its geographical range. Due to its softness, Serebera is regarded to be of poor quality [unpublished observation, 29] and it is locally consumed mainly by children thus limiting the transfer of its germplasm over long distances. In addition, the occurrence of Serebera showed a significant association to $\operatorname{sex}(V=0.201$, $p=0.016$, Table 5) which may still be explained in terms of low quality and being less desired on the market than the firm varieties. Basing on the demographic data, jackfruit business in Uganda was dominated by females, therefore, they were aware of the shortcomings of Serebera as far as marketability was concerned hence fewer female farmers than males grew this variety. Namata though a firm variety, was also considered inferior due to the white colour of its pulps that gives consumers the impression of unripe and less sweet fruits hence less grown than its two firm counter parts (Kanaanansi and Namusaayi). However it is important to note that Namata exhibited weak but significant associations to age range and marital status (Table 5), with 16 $(38.1 \%)$ of 42 households where it occurred belonging to the age group > 57 and 27 (64.3\%) belonging to married respondents. It is however not clear why this is so and requires further investigations. Since jackfruit trees provide wood for timber and fuel (Haq, 2006; Rahman et al., 2016; Sidhu, 2012), the alarming rate of deforestation in Uganda standing at 200, 000 hectares per year (Josephat, 2018) was affecting tree food crops including jackfruit, hence threatening food security. Namata and Serebera which were considered inferior varieties were often selected for timber or fuel while the superior varieties, Kanaanansi and Namusaayi were spared. This kind of selection puts the crop's genetic resource at risk of losing important alleles that may offer the plant survival abilities. Therefore, conservation of the Serebera and Namata germplasm by the National Agricultural Research Organization (NARO) is crucial for ensuring survival and maintenance of variation in the jackfruit population in Uganda. The significant association of the two varieties (Namata and Serebera) to political regions may be due to social interactions with the crop to the extent that the tribes in Eastern and Western regions have no interest in the two varieties. This further shows that germplasm of these two varieties can be obtained from the Central region of Uganda and conservation efforts for these two varieties should take the social aspect into consideration. Basing on the results of this study, germplasm for Serebera can mainly be obtained from Luweero and Mubende districts and Namata from Mityana and Masaka districts. For traders interested in the superior varieties (Kanaanansi and Namusaayi), they can be sufficiently obtained from any district in the three political regions (Central, Eastern and Western) as well as the three agro-ecological zones (LVCMF, SELKB, SWGF). 
Table 4 Distribution of ethno-varieties of jackfruit in sampled districts and political regions

\begin{tabular}{|c|c|c|c|c|c|}
\hline & Folk Varieties & Serebera & Kanaanansi & Namata & Namusaayi \\
\hline Political Region & District sampled & $\begin{array}{l}\text { Frequency } \\
(\%)\end{array}$ & $\begin{array}{l}\text { Frequency } \\
(\%)\end{array}$ & $\begin{array}{l}\text { Frequency } \\
(\%)\end{array}$ & $\begin{array}{l}\text { Frequency } \\
(\%)\end{array}$ \\
\hline \multirow{6}{*}{ Central Region } & Kayunga $(n=15)$ & 0 & $14(93.3)$ & $5(33.3)$ & $12(80.0)$ \\
\hline & Luwero $(\mathrm{n}=11)$ & $7(63.6)$ & $11(100.0)$ & $3(27.3)$ & $11(100.0)$ \\
\hline & Mityana $(n=13)$ & $1(7.7)$ & $11(84.6)$ & $9(69.2)$ & $8(61.5)$ \\
\hline & Masaka $(\mathrm{n}=11)$ & $1(8.3)$ & $11(91.7)$ & $8(66.7)$ & $3(25.0)$ \\
\hline & Mubende $(n=8)$ & $5(62.5)$ & $8(100.0)$ & $2(25.0)$ & $4(50.0)$ \\
\hline & Sembabule $(\mathrm{n}=13)$ & $3(23.1)$ & $11(84.6)$ & $4(30.8)$ & $8(61.5)$ \\
\hline Overall Central & $(n=72)$ & $17(23.6)$ & 67(93.1) & $31(43.1)$ & $46(63.9)$ \\
\hline \multirow[t]{4}{*}{ Eastern Region } & Pallisa(n = 13) & 0 & $11(84.6)$ & $2(15.4)$ & $4(30.8)$ \\
\hline & Kamuli $(\mathrm{n}=10)$ & 0 & 10(100.0) & $1(10.0)$ & $8(80.0)$ \\
\hline & Iganga $(n=14)$ & 0 & $14(100.0)$ & $2(14.3)$ & $12(85.7)$ \\
\hline & Jinja $(\mathrm{n}=11)$ & $2(18.2)$ & $11(100.0)$ & $1(9.1)$ & $11(100.0)$ \\
\hline Overall Eastern & $(n=48)$ & $2(4.2)$ & $46(95.8)$ & 6(12.5) & $35(72.9)$ \\
\hline \multirow[t]{2}{*}{ Western Region } & Ibanda $(\mathrm{n}=12)$ & 0 & 11(91.7) & $2(16.7)$ & $6(50.0)$ \\
\hline & Mbarara $(n=12)$ & $1(8.3)$ & 12(100.0) & $3(25.0)$ & $5(41.7)$ \\
\hline Overall Western & $(n=24)$ & $1(4.2)$ & $23(95.8)$ & $5(20.8)$ & 11(45.8) \\
\hline \multirow{2}{*}{$\begin{array}{l}\text { Overall occurrence } \\
X^{2} \mathrm{p} \text { - Value }\end{array}$} & $\begin{array}{c}\text { Number of farms } \\
(n=144)\end{array}$ & $20(13.9)$ & 136(94.4) & $42(29.2)$ & $42(63.9)$ \\
\hline & & 0.000 & 0.986 & 0.000 & 0.668 \\
\hline
\end{tabular}


Table 5 Association between demographic features and results on classification according to fruit texture and ethno-variety occurrence

\begin{tabular}{|c|c|c|c|c|c|c|c|c|c|c|c|c|}
\hline \multicolumn{5}{|c|}{ Classification according to fruit texture } & \multicolumn{8}{|c|}{ Occurrence of the ethno-varieties } \\
\hline & \multicolumn{2}{|c|}{ Traders } & \multicolumn{2}{|c|}{ Farmers } & \multicolumn{2}{|c|}{ Serebera } & \multicolumn{2}{|c|}{ Namata } & \multicolumn{2}{|c|}{ Kananaansi } & \multicolumn{2}{|c|}{ Namusaayi } \\
\hline Demographic feature & $\mathrm{V}$ & $\mathrm{p}$ & $\mathrm{V}$ & $\mathrm{p}$ & $\mathrm{V}$ & $\mathrm{p}$ & $\mathrm{V}$ & $\mathrm{p}$ & $\mathrm{V}$ & $\mathrm{p}$ & $\mathrm{V}$ & $\mathrm{p}$ \\
\hline Sex & 0.340 & 0.629 & 0.133 & 0.110 & 0.201 & 0.016 & 0.155 & 0.063 & 0.206 & 0.130 & 0.072 & 0.389 \\
\hline Education level & 0.050 & 0.874 & 0.122 & 0.545 & 0.174 & 0.223 & 0.148 & 0.372 & 0.098 & 0.712 & 0.175 & 0.219 \\
\hline Age range & 0.156 & 0.290 & 0.200 & 0.219 & 0.236 & 0.091 & 0.270 & 0.033 & 0.151 & 0.513 & 0.070 & 0.95 \\
\hline Marital status & 0.097 & 0.591 & 0.244 & 0.073 & 0.117 & 0.743 & 0.284 & 0.021 & 0.205 & 0.194 & 0.201 & 0.214 \\
\hline Political region & 0.483 & 0.000 & 0.546 & 0.000 & 0.281 & 0.030 & 0.312 & 0.001 & 0.061 & 0.767 & 0.188 & 0.079 \\
\hline Agro-ecological zone & 0.301 & 0.068 & 0.193 & 0.068 & 0.141 & 0.239 & 0.175 & 0.111 & 0.005 & 0.833 & 0.183 & 0.093 \\
\hline
\end{tabular}

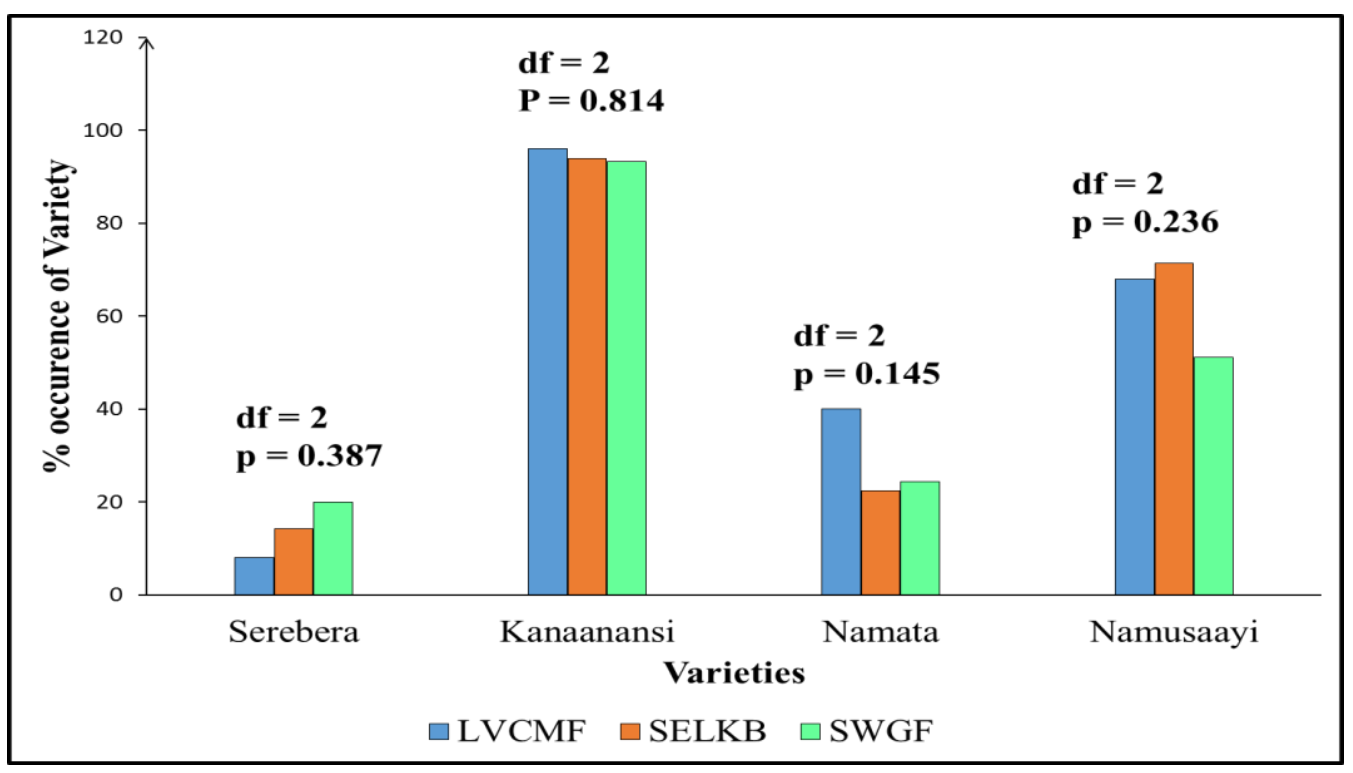

Figure 5: Distribution of ethno-varieties of jackfruit in sampled agro-ecological zones LVCMF = Lake Victoria Crescent and Mbale Farmlands, SELKB = Southern and Eastern Lake Kyoga Basin, SWGF = Southwestern Grass Farmlands

\section{Temporal distribution of jackfruit (Harvesting time of jackfruit)}

Farmer information on harvesting time of jackfruit revealed that jackfruit was generally harvested throughout the year (Figure 6). However, the majority of the farmers reported harvesting fruits in December (LVCMF = $96.0 \%$, SELKB $=100.0 \%$, SWGF $=77.8 \%$ ) and January $(\mathrm{LVCMF}=86.0, \mathrm{SELKB}=93.8 \%$, SWGF $=97.8 \%)$. Moderate harvesting was reported in the month of July (LVCMF $=54.0 \%$, SELKB $=$ $24.5 \%$, SWGF $=53.3 \%)$. These results showed that December and January were the peak months for harvesting jackfruit in Uganda although, jackfruit is available in the country throughout the year (Ndyomugyenyi et al., 2014). Availability of jackfruit in the country throughout the year may be attributed to presence of early and late maturing varieties (Hossain and Haq, 2006; Li et al., 2010), secondary flowering [Field observations] or varieties that yield throughout the year such as the Maharajapuram variety in India (https://theindianvegan.blogspot.com/2012/ 10/all-about-jackfruit-in-india.html) accessed on 21/06/2019. Alternatively, though jackfruit may be widely adapted to climatic conditions in different agro-ecological zones of Uganda, these conditions may affect its phenology patterns (Kishore, 2018) with each agroecological zone having its own pattern hence 
spreading fruit maturity throughout the year. Availability of jackfruit throughout the year has also been reported in Malaysia, Indonesia, Thailand, Australia (Hossain and Haq, 2006) and China (Li et al., 2010). The differences in climatic conditions may be responsible for the different peak seasons of jackfruit among countries for example, jackfruit is in plenty from March to May in Philippines, April to May in Thailand, September to December and June to August in India (https://theindianvegan.blogspot.com/2012/ 10/all-about-jackfruit-in-india.html) accessed on 21/06/2019. Since jackfruit matures at different times in different countries, its availability throughout the year in Uganda may be attributed to multiple introductions of jackfruit germplasm from different countries. Information on differences in peak seasons among countries is relevant to ensure continuous supply and minimize losses during production gluts by exporting to countries that may be experiencing scarcity and January provides an opportunity to Uganda to penetrate the market especially on the European continent where climatic conditions do not favor growth of jackfruit. However, in Uganda, there are some months such as April in LVCMF $(8.0 \%)$ and SELKB $(2.0 \%)$ as well as September in SWGF $(8.2 \%$, Table 6) in which a few farmers reported harvesting jackfruit implying low supply to markets in these months. If the jackfruit market is to be sustained even during these months, there is need to vegetatively multiply the trees that mature in these months or apply chemical stimulants such as paclobutrazol (Lina and Protacio, 2013) to induce jackfruit flowering in order to produce off-season fruits.

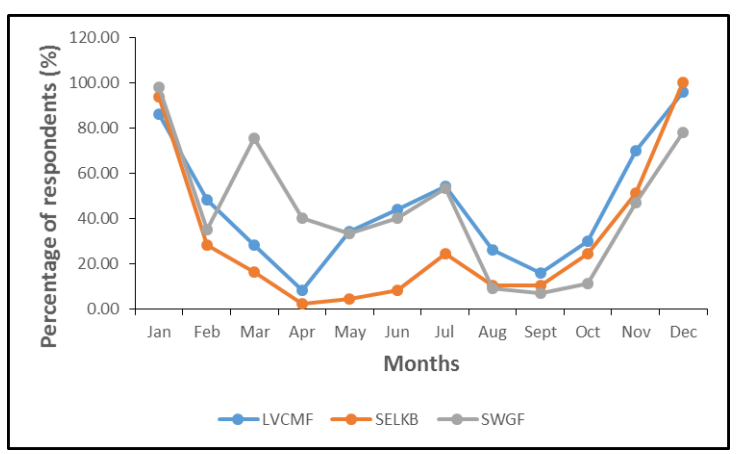

Figure 6: Months of the year when farmers harvest jackfruit in the three Agro-ecological zones. $\mathrm{LVCMF}=$ Lake Victoria Crescent and Mbale Farmlands, SELKB = Southern and
Eastern Lake Kyoga Basin, SWGF = Southwestern Grass Farmlands

\section{Conclusion}

Folk classification of jackfruit varieties in Uganda was based on fruit texture and pulp colour. Therefore, ethno-varieties were given local names that depicted the fruit texture or pulp colour. This information can be used by National Agricultural Research Organization (NARO) as a basis to come up with standardized varieties since SSR analysis revealed variations among the jackfruit ethnovarieties. The Central and Eastern regions were the major jackfruit growing regions supplying the markets in Uganda and the Western region was slowly picking up. Experimental plots should be established by NARO in the Northern region to assess the performance of the crop since the region lagged behind in jackfruit production with no trader obtaining jackfruit from that region. The results also revealed that jackfruit was widely adapted to a range of environmental conditions hence its survival in many of the agro-ecological zones of Uganda. Jackfruit ripens throughout the year though the peak was in December and January. Namata and Serebera varieties need urgent attention to conserve their germplasm since their occurrences were low and would continue to decrease if jackfruit trees were put to use especially for destructive purposes like providing timber and fuel.

\section{Acknowledgements}

We thank the Institutional Review Board of Mbarara University of Science and Technology and Uganda National Council for Science and Technology for reviewing and approving the study. We also express our sincere gratitude to all farmers and traders for their contribution towards the information that is written in this paper. Special thanks goes to Deutscher Akademischer Austausch Dienst (DAAD) for sponsoring the $\mathrm{PhD}$ studies of the corresponding author that have resulted into this work.

\section{Reference}

Berlin, B. (2014). Ethnobiological classification: Principles of categorization of plants and animals in traditional societies (Vol. 185). 
Princeton University Press.

Borines, L. M., Palermo, V. G., Guadalquiver, G. A., Dwyer, C., Drenth, A., Daniel, R., \& Guest, D. I. (2014). Jackfruit decline caused by Phytophthora palmivora (Butler). Australasian Plant Pathology, 43(2), 123-129.

Bose, T. K. (1985). Jackfruit. Fruits of India: Tropical and Subtropical (Mitra BK, Ed.). Naya Prokash, Calcutta, India, 488-497.

Chiputwa, B., \& Qaim, M. (2016). Sustainability standards, gender, and nutrition among smallholder farmers in Uganda. The Journal of Development Studies, 52(9), 12411257.

De Faria, A. F., De Rosso, V. V, \& Mercadante, A. Z. (2009). Carotenoid composition of jackfruit (Artocarpus heterophyllus), determined by HPLC-PDA-MS/MS. Plant Foods for Human Nutrition, 64(2), 108-115.

Dutton, P. R. (1976). Jackfruit: The propagation of TRopical Fruit Trees (J. Garner, R \& A. Chowdhury, S, Eds.). Farm Royal, Slough: Commonwealth Agricultural Bureau.

Esquinas-Alcázar, J. (2005). Protecting crop genetic diversity for food security: political, ethical and technical challenges. Nature Reviews Genetics, 6(12), 946.

Gras, A., Serrasolses, G., Vallès, J., \& Garnatje, T. (2019). Traditional knowledge in semirural close to industrial areas: ethnobotanical studies in western Gironès (Catalonia, Iberian Peninsula). Journal of Ethnobiology and Ethnomedicine, 15(1), 19.

Gwali, S., Okullo, J. B. L., Eilu, G., Nakabonge, G., Nyeko, P., \& Vuzi, P. (2011). Folk classification of Shea butter tree (Vitellaria paradoxa subsp. nilotica) ethno-varieties in Uganda. Ethnobotany Research and Applications, 9, 243-256.

Haq, N. (2006). Jackfruit, Artocarpus heterophyllus. Southampton,Uk.

Hossain, A., \& Haq, N. (2006). Jackfruit. Artocarpus Heterophyllus, Field Manual for Extension Workers and Farmers, SCUC, Southampton University, UK.

Hyten, D. L., Song, Q., Zhu, Y., Choi, I.-Y., Nelson, R. L., Costa, J. M., ... Cregan, P. B.
(2006). Impacts of genetic bottlenecks on soybean genome diversity. Proceedings of the National Academy of Sciences, 103(45), 16666-16671.

Jagadeesh, S. L., Reddy, B. S., Swamy, G. S. K., Gorbal, K., Hegde, L., \& Raghavan, G. S. V. (2007). Chemical composition of jackfruit (Artocarpus heterophyllus Lam.) selections of Western Ghats of India. Food Chemistry, 102(1), 361-365.

Josephat, M. (2018). Deforestation in Uganda: Population increase, forest loss and climate change. Environ Risk Assess Remediat, 2(2), 46-50.

Kakudidi, E. K. (2004). Folk plant classification by communities around Kibale National Park, western Uganda. African Journal of Ecology, 42, 57-63.

Khan, R., Zerega, N., Hossain, S., \& Zuberi, M. I. (2010). Jackfruit (Artocarpus heterophyllus Lam.) diversity in Bangladesh: land use and artificial selection. Economic Botany, 64(2), 124-136.

Kishore, K. (2018). Phenological growth stages of jackfruit (Artocarpus heterophyllus) according to the extended $\mathrm{BBCH}$ scale. Annals of Applied Biology, 172(3), 366-374.

Li, Y.-Z., Qi, M. A. O., Feng, F., \& Ye, C.-H. (2010). Genetic diversity within a jackfruit (Artocarpus heterophyllus Lam.) germplasm collection in China using AFLP markers. Agricultural Sciences in China, 9(9), 1263-1270.

Lina, D. P., \& Protacio, C. M. (2013). Phenology of jackfruit (Artocarpus heterophyllus Lam.) and effects of paclobutrazol on offseason fruit production. II Southeast Asia Symposium on Quality Management in Postharvest Systems 1088, 495-499.

Loko, L. E. Y., Toffa, J., Adjatin, A., Akpo, A. J., Orobiyi, A., \& Dansi, A. (2018). Folk taxonomy and traditional uses of common bean (Phaseolus vulgaris L.) landraces by the sociolinguistic groups in the central region of the Republic of Benin. Journal of Ethnobiology and Ethnomedicine, 14(1), 52.

Madruga, M. S., de Albuquerque, F. S. M., Silva, I. R. A., do Amaral, D. S., Magnani, M., \& Neto, V. Q. (2014). Chemical, 
morphological and functional properties of Brazilian jackfruit (Artocarpus heterophyllus L.) seeds starch. Food Chemistry, 143, 440-445.

Magcale-Macandog, D. B., Rañola, F. M., Rañola, R. F., Ani, P. A. B., \& Vidal, N. B. (2010). Enhancing the food security of upland farming households through agroforestry in Claveria, Misamis Oriental, Philippines. Agroforestry Systems, 79(3), 327-342.

Maia, J. G. S., Andrade, E. H. A., \& Maria das Gracas, B. Z. (2004). Aroma volatiles from two fruit varieties of jackfruit (Artocarpus heterophyllus Lam.). Food Chemistry, 85(2), 195-197.

Mekbib, F. (2007). Infra-specific folk taxonomy in sorghum (Sorghum bicolor(L.) Moench) in Ethiopia: folk nomenclature, classification, and criteria. Journal of Ethnobiology and Ethnomedicine, 3(1), 38. https://doi.org/10.1186/1746-4269-3-38

Mota, A. A., Lachore, S. T., \& Handiso, Y. H. (2019). Assessment of food insecurity and its determinants in the rural households in Damot Gale Woreda, Wolaita zone, southern Ethiopia. Agriculture \& Food Security, 8(1), 11.

Nakintu, J., Albrecht, C., Müller, C. M., KagoroRugunda, G., Andama, M., Olet, E. A., ... Gemeinholzer, B. (2019). Exploring the genetic diversity of jackfruit (Artocarpus heterophyllus Lam.) grown in Uganda based on SSR markers. Genetic Resources and Crop Evolution, 1-15.

Ndyomugyenyi, E. K., Okot, M. W., \& Mutetikka, D. (2014). Production and availability of Jackfruit (Artocarpus heterophyllus) and Java plum (Syzygium cumini) seeds for livestock feeding in Eastern and Central Regions of Uganda. Livestock Research for Rural Development, 26(4), 1-12.

Nuijten, E., \& Almekinders, C. J. M. (2008). Mechanisms explaining variety naming by farmers and name consistency of rice varieties in the Gambia. Economic Botany, 62(2), 148-160.

Oldfield, S. F., Olwell, P., Shaw, N., \& Havens, K. (2019). Conservation of Plant Species. In Seeds of Restoration Success (pp. 41-57).
Springer.

Phaka, F. M., Netherlands, E. C., Kruger, D. J. D., \& Du Preez, L. H. (2019). Folk taxonomy and indigenous names for frogs in Zululand, South Africa. Journal of Ethnobiology and Ethnomedicine, 15(1), 17.

Quiros, C. F., Brush, S. B., Douches, D. S., Zimmerer, K. S., \& Huestis, G. (1990). Biochemical and folk assessment of variability of Andean cultivated potatoes. Economic Botany, 44(2), 254-266.

Rahman, M. H., Patwary, M. M. A., Barua, H., Nahar, S., \& Ahmmed, A. N. F. (2016). Evaluation of yield and quality of three jackfruit (Artocarpus heterophyllus L.) genotypes. The Agriculturists, 14(1), 107111.

Ramires, M., Clauzet, M., \& Begossi, A. (2012). Folk taxonomy of fishes of artisanal fishermen of Ilhabela (São Paulo/Brazil). Biota Neotropica, 12(4), 29-40.

Ranasinghe, R., Maduwanthi, S. D. T., \& Marapana, R. (2019). Nutritional and Health Benefits of Jackfruit (Artocarpus heterophyllus Lam.): A Review. International Journal of Food Science, 2019.

Rao, S. A., Bounphanousay, C., Schiller, J. M., Alcantara, A. P., \& Jackson, M. T. (2002). Naming of traditional rice varieties by farmers in the Lao PDR. Genetic Resources and Crop Evolution, 49(1), 83-88.

Sambatti, J. B. M., Martins, P. S., \& Ando, A. (2001). Folk taxonomy and evolutionary dynamics of cassava: a case study in Ubatuba, Brazil. Economic Botany, 55(1), 93-105.

Shyamalamma, S., Chandra, S. B. C., Hegde, M., \& Naryanswamy, P. (2008). Evaluation of genetic diversity in jackfruit (Artocarpus heterophyllus Lam.) based on amplified fragment length polymorphism markers. Genetics and Molecular Research, 7(3), 645-656.

Sidhu, A. S. (2012). Jackfruit Improvement in the Asia-Pacific Region: A Status Report. APAARI.

Teshome, A., Baum, B. R., Fahrig, L., Torrance, J. K., Arnason, T. J., \& Lambert, J. D. (1997). Sorghum [Sorghum bicolor (L.) 
Moench] landrace variation and classification in north Shewa and south Welo, Ethiopia. Euphytica, 97(3), 255-263.

Tibuhwa, D. D. (2012). Folk taxonomy and use of mushrooms in communities around Ngorongoro and Serengeti National Park, Tanzania. Journal of Ethnobiology and Ethnomedicine, 8(1), 36.

Turyagyenda, L. F., Kizito, E. B., Ferguson, M. E., Baguma, Y., Harvey, J. W., Gibson, P., ... Osiru, D. S. O. (2012). Genetic diversity among farmer-preferred cassava landraces in Uganda. African Crop Science Journal, 20(1).

Ulicsni, V., Svanberg, I., \& Molnár, Z. (2013). Folk knowledge of non-domestic mammals among ethnic Hungarians in North-Western Romania. North-Western Journal of Zoology, 9(2), 383-398.

Ulicsni, V., Svanberg, I., \& Molnár, Z. (2016). Folk knowledge of invertebrates in Central Europe-folk taxonomy, nomenclature, medicinal and other uses, folklore, and nature conservation. Journal of Ethnobiology and Ethnomedicine, 12(1), 47.

Wang, H. Y. (2011). Development of SSR Markers For Jackfruit And Its Utilisation in Genetic Diversity Analysis. Guangdong Ocean University.

Wortmann, C. S., \& Eledu, C. A. (1999). Uganda's agro ecological zones: A guide to planners and policymakers Centro Internationale de Agricultural Tropical CIAT. Kawanda, Uganda. 